\title{
Estrogen Prevents the Lipopolysaccharide-Induced Inflammatory Response in Microglia
}

\author{
Elisabetta Vegeto, ${ }^{1}$ Cinzia Bonincontro, ${ }^{1}$ Giuseppe Pollio, ${ }^{1}$ Angelo Sala, ${ }^{2}$ Serena Viappiani, ${ }^{2}$ \\ Francesca Nardi,, ${ }^{2}$ Alessia Brusadelli, ${ }^{1}$ Barbara Viviani, ${ }^{2}$ Paolo Ciana, ${ }^{1}$ and Adriana Maggi ${ }^{1}$ \\ ${ }^{1}$ Milano Molecular Pharmacology Lab, and 2Institute of Pharmacological Sciences, University of Milan, 20133 Milan, Italy
}

\begin{abstract}
After neuronal injury and in several neurodegenerative diseases, activated microglia secrete proinflammatory molecules that can contribute to the progressive neural damage. The recent demonstration of a protective role of estrogen in neurodegenerative disorders in humans and experimental animal models led us to investigate whether this hormone regulates the inflammatory response in the CNS. We here show that estrogen exerts an anti-inflammatory activity on primary cultures of rat microglia, as suggested by the blockage of the phenotypic conversion associated with activation and by the prevention of lipopolysaccharide-induced production of inflammatory mediators: inducible form of NO synthase (iNOS), prostaglandin- $\mathrm{E}_{2}\left(\mathrm{PGE}_{2}\right)$, and metalloproteinase-9 (MMP-9). These effects are dose-dependent, maximal at $1 \mathrm{~nm} 17 \beta$ -
\end{abstract}

Microglia are macrophage-like cells of the CNS. Similarly to the other glial cells, microglia play a beneficial role in neural cell viability and survival by producing growth factors and removing potentially toxic cellular debris. However, like macrophages, these cells may be induced by several stimuli to become activated and secrete a diverse range of mediators of the inflammatory cascade, including nitric oxide (NO), proteases, arachidonic acid (AA) derivatives, and cytokines. This change is associated with morphological alterations, which represent the hallmark for the reactive phenotype of these cells.

Increased levels of these inflammatory components and microglia activation have been localized at the sites of neurodegeneration in several disorders, like Alzheimer's (AD), multiple sclerosis, AIDS-associated dementia, and post-traumatic lesions. These observations led us to hypothesize that a chronic inflammatory reaction, driven mainly by reactive microglia, may contribute to the process of neuronal loss and matrix destruction observed in these chronic disorders (Kreutzberg, 1996; Gonzalez-Scarano and Baltuch, 1999).

Among the secretory products mostly associated with the microglial-induced neurotoxicity, NO, prostaglandins, and matrix metalloproteases (MMPs) play a pivotal role. Several studies

\footnotetext{
Received Aug. 2, 2000; revised Nov. 27, 2000; accepted Dec. 15, 2000.

This work was supported by grants from the Italian Association of Cancer Research, MURST 40\%, Consiglio Nazionale delle Ricerche Targeted Project Biotechnology, Telethon, and CEE BioMed Project BMH4-CT97-2286. We greatly acknowledge Clara Meda and Monica Rebecchi for their skilful technical assistance. We also thank Silvia Belcredito, Massimo Brianza, G. Levi, L. Minghetti, and Laura Bolzoni for their experimental support and helpful discussion and Geoffrey Greene for kindly providing us with the ER- $\alpha$ antibodies.

Correspondence should be addressed to Adriana Maggi, Milano Molecular Pharmacology Lab, University of Milan, Via Balzaretti, 9, 20133 Milan, Italy. E-mail: adriana.maggi@unimi.it.

Copyright (C) 2001 Society for Neuroscience $0270-6474 / 01 / 211809-10 \$ 15.00 / 0$
}

estradiol, and can be blocked by the estrogen receptor (ER) antagonist ICl 182,780 . The demonstration of $\mathrm{ER} \alpha$ and $\mathrm{ER} \beta$ expression in microglia and macrophages and the observation of estrogen blockade of MMP-9 mRNA accumulation and MMP-9 promoter induction further support the hypothesis of a genomic activity of estrogen via intracellular receptors. This is the first report showing an anti-inflammatory activity of estrogen in microglia. Our study proposes a novel explanation for the protective effects of estrogen in neurodegenerative and inflammatory diseases and provides new molecular and cellular targets for the screening of ER ligands acting in the CNS.

Key words: estrogen; microglia; macrophage; iNOS; $P G E_{2}$; MMP-9

have shown a correlation between the synthesis of the inducible form of NO synthase (iNOS), the release of NO by microglia, and the progression of neurodegeneration, both in vivo and in vitro (Boje and Arora, 1992; Chao et al., 1992). These observations are substantiated by the results in human neurodegenerative diseases and in the correspondent experimental animal models (Bo et al., 1994; Bagasra et al., 1995; Van Dam et al., 1995; Adamson et al., 1996; Liberatore et al., 1999). Similarly, the levels of prostaglandins and of their synthetic enzyme, cyclo-oxygenase-2 (COX-2), are increased in neurological disorders; consistent with this hypothesis is the reduced incidence of AD in clinical studies with COX-2 inhibitors (Shimizu and Wolfe, 1990; McGeer and McGeer, 1996). MMP-9 expression is associated with malignant, degradative, and chronic inflammatory diseases (BrikedalHansen, 1993; Pagenstecher et al., 1998; Yong et al., 1998; Matrisian, 1999), and its potential role in the manifestation of AD is suggested by its upregulation induced by $\beta$-amyloid peptides (Deb and Gottschall, 1996; Gottshall, 1996).

Several studies have reported that estrogen replacement therapy delays the onset of neurodegenerative disorders, including AD (Honjo et al., 1995; Tang et al., 1996; Kawas et al., 1997), and high levels of circulating estrogens are associated with the remission of inflammatory-related diseases (Horowits, 1993; Nathan and Chaudhuri, 1997). It is well known that estrogen modulates target cell activity by binding to specific intracellular receptors, which are hormone-regulated transcription factors (Katzenellenbogen et al., 1996; Kuiper et al., 1996). Hormone-activated estrogen receptors (ERs) may modulate gene transcription by direct binding to promoters containing an estrogen responsive element (ERE) or via the interaction with other transcription factors (McKay and Cidlowsky, 1999; Webb et al., 1999) or unidentified membrane receptor (Gu and Moss, 1996; Norfleet et al., 2000). 
However, the mechanism involved in the estrogen protective effects on neurodegeneration is poorly understood.

We recently showed that estrogen receptors regulate monocyte survival (Vegeto et al., 1999) and inflammation in different cell systems (Zancan et al., 1999; Cuzzocrea et al., 2000). On the basis of these observations, we hypothesized that estrogen may modulate the reactivity of the resident inflammatory cells of the CNS; thus, we investigated whether this hormone modulates the production of inflammatory mediators in microglia and macrophages.

\section{MATERIALS AND METHODS}

\section{Microglial cell culture}

Microglial cells were isolated from cultures of newborn rat brains, as previously described (Giulian and Baker, 1986). Briefly, cerebral cortices were isolated from 2-d-old Sprague Dawley rats (Charles River, Milan, Italy), stripped of the meninges, minced in $7.5 \mathrm{ml}$ of HBSS (Sigma, Milan, Italy) containing $10 \mathrm{~mm}$ HEPES buffer, dissociated by trituration, and digested in the presence of $0.25 \%$ trypsin (Life Technologies, Milan, Italy) and $1 \mathrm{mg} / \mathrm{ml}$ DNase (Sigma) for $15 \mathrm{~min}$ at $37^{\circ} \mathrm{C}$. Glial cells $(3 \times$ $10^{5} / \mathrm{ml}$ ) were grown at $37^{\circ} \mathrm{C}$ in MEM medium (Life Technologies), supplemented with $0.6 \%$ glucose, $20 \%$ fetal bovine serum (FBS) (Oxoid, Milan, Italy), $1 \%$ nonessential amino acids, $100 \mu \mathrm{g} / \mathrm{ml}$ streptomycin, and $100 \mathrm{IU} / \mathrm{ml}$ penicillin (Life Technologies), at $37^{\circ} \mathrm{C}$ under a humidified $5 \%$ $\mathrm{CO}_{2}$ and $95 \%$ air atmosphere, in $75 \mathrm{~cm}^{2}$ flasks (Corning, Acton, MA) at a density of $3 \times 10^{6}$ cells per flask. Cells were cultured for $8-10 \mathrm{~d}$, and medium was replaced every $3 \mathrm{~d}$. Two days before the experiment, microglia were harvested by gentle shaking at $4^{\circ} \mathrm{C}$ for $30 \mathrm{~min}$ and for additional $2 \mathrm{hr}$ at room temperature. Microglia suspension was centrifuged for $5 \mathrm{~min}$ at $800 \times \mathrm{g}$, and the cell pellet was resuspended in $10 \%$ FBS-MEM at the density of $4 \times 10^{5} \mathrm{cells} / \mathrm{ml} ; 500 \mu \mathrm{l} /$ well of this suspension was seeded in 24 well plates. At this stage, the purity of microglia preparations was $\sim 95-98 \%$, as detected by staining with the ED-1 antibody (Serotec, Oxford, UK), which recognizes a glycoprotein expressed predominantly in myeloid cells and Isolectin-B4 (Sigma) which binds $\alpha$-D-galactosyl conjugates in microglia. For hormone treatments, cells were grown for $24 \mathrm{hr}$ before replacing the medium with serum-free, phenol red-free DMEM (Life Technologies) supplemented with $5 \mathrm{~mm}$ L-glutamine, and antibiotics. Then, cells were incubated in the absence or presence of $17 \beta$-estradiol (Sigma) in freshly added serum-free, phenol red-free DMEM, for $4 \mathrm{hr}$ or the indicated time before additional $16 \mathrm{hr}$ incubation with $0.5-5.0 \mu \mathrm{g} / \mathrm{ml}$ of Escherichia coli lipopolysaccharide (LPS) (serotype 0.111:B4; Sigma). This endotoxin, a cell wall component of Gram-negative bacteria, is known to induce inflammation in different physiological and experimental settings.

\section{Isolation and culture of monocyte-derived macrophages}

Mononuclear cells were isolated from venous blood of healthy donors by a Ficoll-Paque density gradient centrifugation. Cell suspension was plated on $100 \mathrm{~mm}$ culture dishes (for Northern analysis) or on 5\% gelatin-coated coverslips in 24 well plate (for immunocytochemistry) at the final density of $30 \times 10^{6}$ cells $/ \mathrm{ml}$ and incubated at $37^{\circ} \mathrm{C}$ for $1 \mathrm{hr}$ in DMEM. Adherent monocytes were washed twice in PBS and incubated for $7 \mathrm{~d}$ in DMEM, supplemented with $10 \%$ FBS, $24 \mathrm{~mm} \mathrm{NaHCO}_{3}, 25 \mathrm{~mm}$ HEPES, $1 \%$ nonessential amino acids, $5 \mathrm{~mm}$ L-glutamine, $1 \mathrm{~mm}$ sodium pyruvate, $100 \mu \mathrm{g} / \mathrm{ml}$ streptomycin, and $100 \mathrm{IU} / \mathrm{ml}$ penicillin, at $37^{\circ} \mathrm{C}$ under a humidified $5 \% \mathrm{CO}_{2}$ and $95 \%$ air atmosphere.

\section{Cell culture}

SK-NBE and MCF-7 cells were grown at $37^{\circ} \mathrm{C}$ in RPMI 1640 (Sigma) supplemented with $10 \%$ FBS, $1 \%$ nonessential amino acids, $5 \mathrm{~mm}$ L-glutamine, $100 \mu \mathrm{g} / \mathrm{ml}$ streptomycin, and $100 \mathrm{IU} / \mathrm{ml}$ penicillin, at $37^{\circ} \mathrm{C}$ under a humidified $5 \% \mathrm{CO}_{2}$ and $95 \%$ air atmosphere. Cells were split once a week and plated in $10 \mathrm{~cm}^{2}$ Petri dishes (Corning, Acton, MA) at a density of $0.2 \times 10^{5}$ cells $/ \mathrm{ml}$; medium was replaced on the fourth day. For transient transfection experiments, $2 \times 10^{5}$ cells per plate were seeded in 24 well plates in $500 \mu$ l of RPMI 1640 without phenol red (Sigma) with $10 \%$ charcoal-treated FBS (DCC-FBS).

\section{Immunocytochemistry}

For immunocytochemistry, microglia were grown in 24 well plate on glass coverslips for $48 \mathrm{hr}$, then fixed for $5 \mathrm{~min}$ in $4 \%$ paraformaldehyde in $0.1 \mathrm{M}$ phosphate buffer, $\mathrm{pH} 7.2$, at room temperature, washed three time in $0.2 \mathrm{M}$ phosphate buffer, and stored at $4^{\circ} \mathrm{C}$ in $0.01 \mathrm{M} \mathrm{PBS}, \mathrm{pH}$ 7.4. Before the immunological assay, cells were incubated in $0.05 \mathrm{M} \mathrm{NH}_{4} \mathrm{Cl}$ in PBS for $20 \mathrm{~min}$ at room temperature, to saturate aldehyde residues, and then washed in PBS. All primary and secondary antibodies were diluted in PBS containing 3\% BSA. After the immunodetection, glass coverslips were mounted using 50\% glycerol in PBS. Immunoreactivity was observed with a Zeiss Axioskop Microscope (Zeiss, Milan, Italy).

ED-1 staining. Cells were incubated for 5 min in $1 \% \mathrm{H}_{2} \mathrm{O}_{2}$ in $\mathrm{PBS}$ at room temperature, to inhibit endogenous peroxidases, then washed three times with PBS and incubated with $10 \%$ horse serum in blocking solution $(0.1 \%$ Triton $\mathrm{X}-100$ and $3 \% \mathrm{BSA}$ in PBS) at room temperature for 30 min. ED-1 monoclonal antibody was added at the final concentration of $1 \mu \mathrm{g} / \mathrm{ml}$ in PBS at $4^{\circ} \mathrm{Co} / \mathrm{n}$. Cells were washed three times for $10 \mathrm{~min}$ before the incubation with the biotinylated horse anti-mouse IgG (Vector Laboratories, Burlingame, CA) for $75 \mathrm{~min}$ at room temperature. After washing the cells, the staining was obtained by the incubation with the avidin-biotin-horseradish peroxidase complex (ABC kit; Vector Laboratories) and the 3,3'-diaminobenzidine (DAB) substrate (Sigma), as suggested by the manufacturers. A semiquantitative analysis of the extent of microglia activation was obtained by counting fields of $\sim 50$ cells for each treatment. Cells highly ramified and with elongated cell body were counted as resting; amoeboid cells were considered as activated. Each experiment was done in duplicates, and samples were blind counted.

iNOS staining. Cells were washed three times with PBS and incubated with $10 \%$ swine serum in blocking solution. A 1:100 dilution of the polyclonal anti-rat iNOS antibody (Transduction Laboratories, Lexington, $\mathrm{KY}$ ) was added for $3 \mathrm{hr}$ at room temperature. Cells were washed three times before incubation with a swine anti-rabbit IgG conjugated with TRITC (Dako, Milan, Italy) for $90 \mathrm{~min}$ at room temperature. iNOS immunoreactivity was observed with a Zeiss Axioskop Microscope. For each treatment, 5 fields of $\sim 50$ cells each were counted first with a phase-contrast light (to obtain the total cell number) and then under fluorescence emission (to count iNOS-positive cells).

ER- $\alpha$ staining. After incubation in $1 \% \mathrm{H}_{2} \mathrm{O}_{2}$ in PBS, cells were washed three times and incubated with $10 \%$ goat serum in blocking solution as above. Microglia were incubated with $5 \mu \mathrm{g} / \mathrm{ml}$ in PBS of the rabbit anti-rat ER- $\alpha$ polyclonal antibody (ER-21; from G. Greene, University of Chicago), human macrophages with the anti-human ER- $\alpha$ monoclonal antibody (H222; from G. Greene) at the final concentration of $1 \mu \mathrm{g} / \mathrm{ml}$ in PBS; incubation was performed overnight $(\mathrm{o} / \mathrm{n})$ at $4^{\circ} \mathrm{C}$. Cells were washed three times before incubation with the biotinylated goat antirabbit and horse anti-mouse IgGs (Vector Laboratories) for microglial and human macrophage cells, respectively, for $75 \mathrm{~min}$. The staining was obtained by incubation with the ABC-DAB reaction, as described above.

\section{Nitrite assay}

$\mathrm{NO}_{2}{ }^{-}$production was determined in the cell culture supernatants by the Griess reaction, as previously described (Zancan et al., 1999). Briefly, $200 \mu \mathrm{l} /$ well of the supernatant were placed in a 96 well plate, and $20 \mu \mathrm{l}$ of $6.5 \mathrm{~m}$ hydrochloric acid and $20 \mu \mathrm{l}$ of $37.5 \mathrm{~mm}$ sulfanilic acid were added. After incubation for $10 \mathrm{~min}$ at room temperature, $20 \mu \mathrm{l}$ of 12.5 mM $N(1$-napthyl)ethylendiamine was added. Optical density was read at $550 \mathrm{~nm}$ (Multiskan MCC; Flow Laboratories, Helsinki, Finland) $30 \mathrm{~min}$ later and compared with a standard curve.

\section{Prostaglandin- $E_{2}$ assay}

Analysis of prostaglandin- $\mathrm{E}_{2}\left(\mathrm{PGE}_{2}\right)$ was performed on aliquots of cell supernatant without previous purification. The assay was performed in 96 well plates coated with a goat anti-mouse IgG Mab (Cayman Chemical Company, Ann Arbor, MI). Samples at different dilutions and $\mathrm{PGE}_{2}$-acetylcholinesterase conjugate (Cayman Chemical Company; 50 $\mu \mathrm{l} /$ well), were added to compete for specific binding to a specific monoclonal anti-PGE $\mathrm{P}_{2}$ antibody (Cayman Chemical Company; $50 \mu \mathrm{l} /$ well). After incubation for $1 \mathrm{hr}$ at room temperature and for $18 \mathrm{hr}$ at $4{ }^{\circ} \mathrm{C}$, unbound reagents were removed by washing (phosphate buffer $10 \mathrm{~mm}$, pH 7.4, 0.05\% Tween 20 Titertek Microplate Washer S8/12, Flow Laboratories), and the amount of bound eicosanoid-acetylcholinesterase conjugate was measured by addition of Ellman's reagent (Cayman Chemical Company; $200 \mu \mathrm{l} /$ well) by a Titertek Autodrop (Labsystem and Flow Laboratories). Absorbance was measured at $414 \mathrm{~nm}$. Quantitation of the samples was made using a standard curve of synthetic $\mathrm{PGE}_{2}$, ranging from $1 \mathrm{ng} / \mathrm{ml}$ to $8 \mathrm{pg} / \mathrm{ml}$. Cross-reactivity of the antibody was $<1 \%$ for all natural prostaglandins. 


\section{Zymography}

To identify proteins with gelatinolytic activity secreted by microglia, we used SDS-polyacrylamide gels containing $1 \mathrm{mg} / \mathrm{ml}$ gelatin, following a procedure described in the literature (Gottshall et al., 1995). Briefly, 35 $\mu \mathrm{l}$ of conditioned media was subjected to electrophoresis at $180 \mathrm{~V}$ for 1 hr; gels were washed in 2.5\% Triton X-100 $(2 \times 15 \mathrm{~min})$ and incubated overnight at $37^{\circ} \mathrm{C}$ in $50 \mathrm{~mm}$ Tris- $\mathrm{HCl}, \mathrm{pH} 7.4$, containing $10 \mathrm{~mm} \mathrm{CaCl}_{2}$. Gels were stained with $0.1 \%$ Coomassie brilliant blue R-250 (Sigma) diluted in $30 \%$ methanol and $10 \%$ acetic acid and destained until clear bands appeared on a uniformly stained background. Semiquantitative estimation of band intensity was performed by optical densitometric scanning.

\section{RT-PCR and Southern blot analysis}

$R N A$ preparation. RNA preparation was performed as previously described (Chomczynski and Sacchi, 1987). Briefly, the RNA denaturing solution containing $4 \mathrm{M}$ guanidinium thiocyanate in $25 \mathrm{~mm}$ sodium citrate, $\mathrm{pH} 7,0.6 \%$ sarcosyl, and $0.1 \mathrm{~m}$ 2-mercaptoethanol was added directly to the cell culture at the concentration of $1 \times 10^{6}$ cells $/ \mathrm{ml}$; cell suspension was removed with a rubber scraper and processed. Uterus and liver from young female rats (250 gm weight) were homogenized in RNA denaturing solution.

cDNA preparation, PCR, and Southern blot. These reactions were performed as previously described (Vegeto et al., 1999). Briefly, after DNase digestion, phenol-chloroform extraction, and ethanol precipitation, $1 \mu \mathrm{g}$ of RNA was denatured at $68^{\circ} \mathrm{C}$ with $10 \mathrm{pmol}$ of oligo- $\mathrm{dT}_{(12-18)}$ (Perkin-Elmer, Milan, Italy) in $10 \mu$ l final volume. Oligo-dT/RNA mixes were cooled at room temperature for $15 \mathrm{~min}$, deoxynucleotide triphosphate (dNTP) (Pharmacia, Milan, Italy) and Moloney murine leukemia virus reverse transcriptase (RT) (Promega, Milan, Italy) were added at $200 \mu \mathrm{M}$ and $1 \mathrm{U} / \mu \mathrm{l}$ final concentration, respectively, in a final volume of $20 \mu \mathrm{l}$. The RT reaction was performed at $37^{\circ} \mathrm{C}$ for $1 \mathrm{hr}$, the enzyme was inactivated at $75^{\circ} \mathrm{C}$ for $5 \mathrm{~min}$, and cDNA suspensions were stored at $-20^{\circ} \mathrm{C}$ in $100 \mu \mathrm{l}$ of final volume. Control reactions without addition of the RT enzyme were performed for each sample; no bands were detected in the subsequent hybridizations.

Three microliters of cDNA mix were incubated with $400 \mathrm{~nm}$ dNTP, $200 \mathrm{~nm}$ each primer, and $2 \mathrm{U}$ of DynaZyme DNA polymerase (Finezyme OY, Espoo, Finland) in $100 \mu \mathrm{l}$ of final volume. For both cDNA amplification and probe generation for Southern blot hybridization, the following primers (MWG Biotech, Ebersberg, Germany) were used: for rat ER- $\alpha$, primers $\mathrm{r} \alpha_{1554 \mathrm{a}}\left(5^{\prime}\right.$-gtgccggatatgggaaaggatg- $\left.3^{\prime}\right)$ and $\mathrm{r} \alpha_{1775 \mathrm{~b}}\left(5^{\prime}-\right.$ gaagagtttgtgtgcctcaaat- $\left.3^{\prime}\right)$; for rat $\mathrm{ER} \beta$, primers $\mathrm{r} \beta_{39 \mathrm{a}}$ (5'tccctctttgcgtttggacta- $\left.3^{\prime}\right)$ and $\mathrm{r} \beta_{301 \mathrm{~b}}\left(5^{\prime}\right.$-ttcccggcagcaccagtaacc- $\left.3^{\prime}\right)$. For human ER- $\alpha$, primers $h \alpha-6_{1539 a}\left(5^{\prime}\right.$-aatgtgtagaggggcatgg- $\left.3^{\prime}\right)$ and $\mathrm{h} \alpha-7_{1835 \mathrm{~b}}\left(5^{\prime}\right.$-tgatgtgggagaggatagg-3'); for human ER $\beta$, primers $\mathrm{h} \beta_{33 \mathrm{a}}$ $\left(5^{\prime}\right.$-tcccagcaatgtcactaac- $\left.3^{\prime}\right)$ and $\mathrm{h} \beta_{252 \mathrm{~b}}\left(5^{\prime}\right.$-tccccactaaccttccttt- $\left.3^{\prime}\right)$. For rat
MMP-9, primers rat-M9-350A (5'-ggcaccatcataacatca- $\left.3^{\prime}\right)$ and rat-M9$625 \mathrm{~B}\left(5^{\prime}\right.$-gcccagcgaccacaactc- $\left.3^{\prime}\right)$. Reaction products were: $221 \mathrm{bp}$ for rat ER- $\alpha, 262$ bp for rat ER- $\beta, 296$ bp for human ER- $\alpha, 219$ bp for human ER- $\beta$, and 293 bp for rat MMP-9. Amplification of the constitutively expressed enzyme glyceraldehyde phosphodehydrogenase (GAPDH) was performed in parallel to assess the reverse transcriptase reaction efficiency; similar levels of GAPDH products were obtained from rat microglia cells, uterus, and liver, and from human macrophages and MCF-7 cells. The PCR reactions were performed as follows: $95^{\circ} \mathrm{C}$ for 5 min followed by 40 cycles at $92^{\circ} \mathrm{C}$ for $1 \mathrm{~min}, 50^{\circ} \mathrm{C}\left(56^{\circ} \mathrm{C}\right.$ for MMP-9) for $1 \mathrm{~min}$, and $72^{\circ} \mathrm{C}$ for $1 \mathrm{~min}$. PCR reactions were performed on a PerkinElmer Thermal Cycler 480.

pSVwt-hER (from P. Chambon, Institut National de la Santé et de la Recherche Médicale, Strasbourg, France) and pCMV5-hER $\beta$ (from J.-A. Gustaffson, University of Huddinge, Sweden) plasmids were used as templates for the preparation DNA probes labeled with digoxygenin (Roche, Milan, Italy) by means of PCR; probes corresponded to nucleotides from 1539 to 1835 of the human ER- $\alpha$ cDNA plasmid (pSVwthER) and to nucleotides from 33 to 252 of the human ER- $\beta$ cDNA plasmid (pCMV5-hER $\beta$ ).

Electrophoresis, blotting, and hybridization. Ten microliters of each PCR product were loaded on $2 \%$ agarose gel in Tris-borate EDTA and subjected to electrophoresis. After gel denaturation and neutralization, DNA was transferred onto nylon membrane (Hybond-N; Amersham Pharmacia Biotech, Uppsala, Sweden) by capillary blotting and fixed to the membrane by UV irradiation and baking at $80^{\circ} \mathrm{C}$ for $24 \mathrm{hr}$. After two subsequent prehybridizations, heat-denatured Dig-11dUTP-labeled probes were hybridized at $42^{\circ} \mathrm{C} \mathrm{o} / \mathrm{n}$. After several washes, enhanced chemiluminescent reaction was performed as specified by the manufacturer (Boehringer-Roche, Milan, Italy).

\section{Northern blot analysis}

$R N A$ preparation. RNA preparation was performed as described in the previous section.

Probe preparation. The p92 plasmid (from G. Goldberg, New York State University, Buffalo, NY) was digested with $\mathrm{XbaI}$ to excise the cDNA of human MMP-9, which was labeled with the DNA Megaprime Labeling System purchased from Amersham, using ${ }^{32} \mathrm{P}$-dCTP (Amersham Pharmacia Biotech) to a specific activity of $5 \times 10^{8} \mathrm{dpm} / \mathrm{mg}$.

Electrophoresis, blotting, and hybridization. Five micrograms of total RNA were loaded on a $1 \%$ denaturing agarose gel containing $2.2 \mathrm{M}$ formaldehyde. Electrophoresis was conducted at $100 \mathrm{~V}$ for $2 \mathrm{hr}$ in $1 \times$ [3-( $N$-morpholino)-propanesulfonic acid] running buffer. Equal loading was confirmed by densitometric scanning of the 18S RNA bands obtained from a photograph of the gel. RNA was transferred to a positively charged nylon membrane (Nylon-N ${ }^{+}$; Amersham Pharmacia Biotech) by capillary blotting. After $1 \mathrm{hr}$ prehybridization at $68^{\circ} \mathrm{C}$ in Quick-Hyb
A

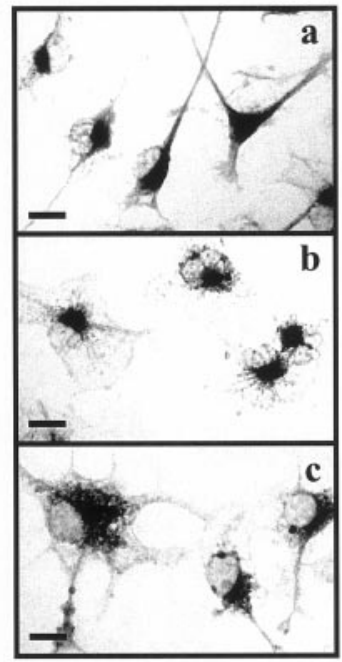

ED-1
B

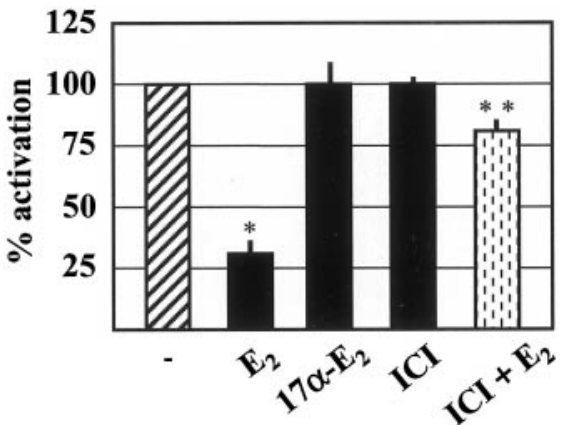

C

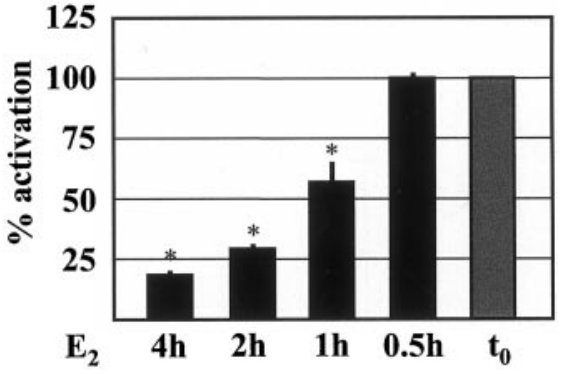

Figure 1. LPS-induced morphological activation is prevented by estrogen in primary cultures of rat microglia. $A$, ED-1 immunocytochemistry analysis in microglial cells treated for $16 \mathrm{hr}$ in the absence $(a)$ or presence of $0.5 \mu \mathrm{g} / \mathrm{ml}$ LPS $(b)$ or LPS +1 nM $17 \beta$-estradiol $(c)$ added $4 \mathrm{hr}$ before the endotoxin. $B, C$, Quantitative assessment of the morphological changes induced by LPS alone $(-)$ and $17 \beta$-estradiol $\left(E_{2}\right), 17 \alpha$-estradiol $\left(17 \alpha-E_{2}\right)$, ICI $182,780(I C I)$, or ICI together with $17 \beta$-estradiol $\left(I C I+E_{2}\right)(B)$ or $17 \beta$-estradiol at different time intervals: $4,2,1$, and $0.5 \mathrm{hr}$ before or simultaneously $\left(t_{0}\right)$ with LPS $(C)$. Values represent the percentage of activated per total cells and are the mean \pm SD of three separate experiments performed in triplicate samples. ${ }^{*} p<$ 0.05 , as compared with the LPS-treated values, ${ }^{* *} p<0.05$, as compared with the LPS and LPS $+\mathrm{E}_{2}$-treated values, were calculated by ANOVA test, followed by a Bonferroni analysis. Photographs were made by using a 990 Coolpix digital photocamera (Nikon, Milan, Italy), then visualized and printed using standard computer programs. Scale bars, $30 \mu \mathrm{m}$. 
Figure 2. LPS-induced iNOS synthesis and $\mathrm{NO}_{2}{ }^{-}$accumulation is attenuated by estrogen in microglia. $A-F$, iNOS immunocytochemistry analysis in microglial cells treated for $16 \mathrm{hr}$ in the absence (control; $A, D$ ) or presence of $0.5 \mu \mathrm{g} / \mathrm{ml}$ LPS $(L P S ; B, E)$ or LPS +1 nм $17 \beta$-estradiol $\left(L P S+E_{2} ; C, F\right)$. $G, H$, Quantitative assessment of iNOS expression. iNOS immunoreactivity was calculated by counting cells first with a phasecontrast light (corresponding to the total cell number) and then under fluorescence emission (iNOS-positive cells). $I, J$, Supernatants from primary cultures of rat microglia were analyzed for $\mathrm{NO}_{2}{ }^{-}$content, as described in Materials and Methods. Microglial cells were assayed in the absence (empty boxes) or presence of $1 \mathrm{~nm} 17 \beta$-estradiol $\left(E_{2}\right.$; light gray boxes) or by adding LPS alone (dashed boxes) or in the presence of $\mathrm{E}_{2}$ added $4 \mathrm{hr}$ before LPS (black boxes) or together with the bacterial endotoxin (dark gray boxes), in the

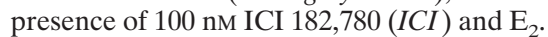
Increasing molar concentrations of $\mathrm{E}_{2}$ were assayed with $0.5 \mu \mathrm{g} / \mathrm{ml}$ LPS $(G, I)$, whereas increasing concentrations of LPS were assayed with $1 \mathrm{~nm}$ estrogen $(J)$. $\mathrm{NO}_{2}{ }^{-}$values from untreated cells or from cells treated with $1 \mathrm{~nm} \mathrm{E}_{2}$ alone were below the detectable limit $(0.09 \mu \mathrm{g} / \mathrm{ml})$. Values represent the mean \pm SD of triplicate determinations and are representative of at least three separate experiments. ${ }^{\circ} p<0.01$, as compared with the control; ${ }^{*} p<0.05$, as compared with the LPS-treated values, and $* *<0.05$, as compared with both LPS and LPS $+\mathrm{E}_{2}$ values, were calculated by ANOVA test, followed by a Bonferroni analysis. Cells were photographed on Eastman Kodak (Rochester, NY) 200 ASA films using direct $(A-C)$ or phase-contrast light $(D-F)$; identical areas of cell culture photographed in $A-C$ were analyzed under fluorescent emission $(D-F)$ and photographed on 400 ASA films. Scale bars, $200 \mu \mathrm{m}$.
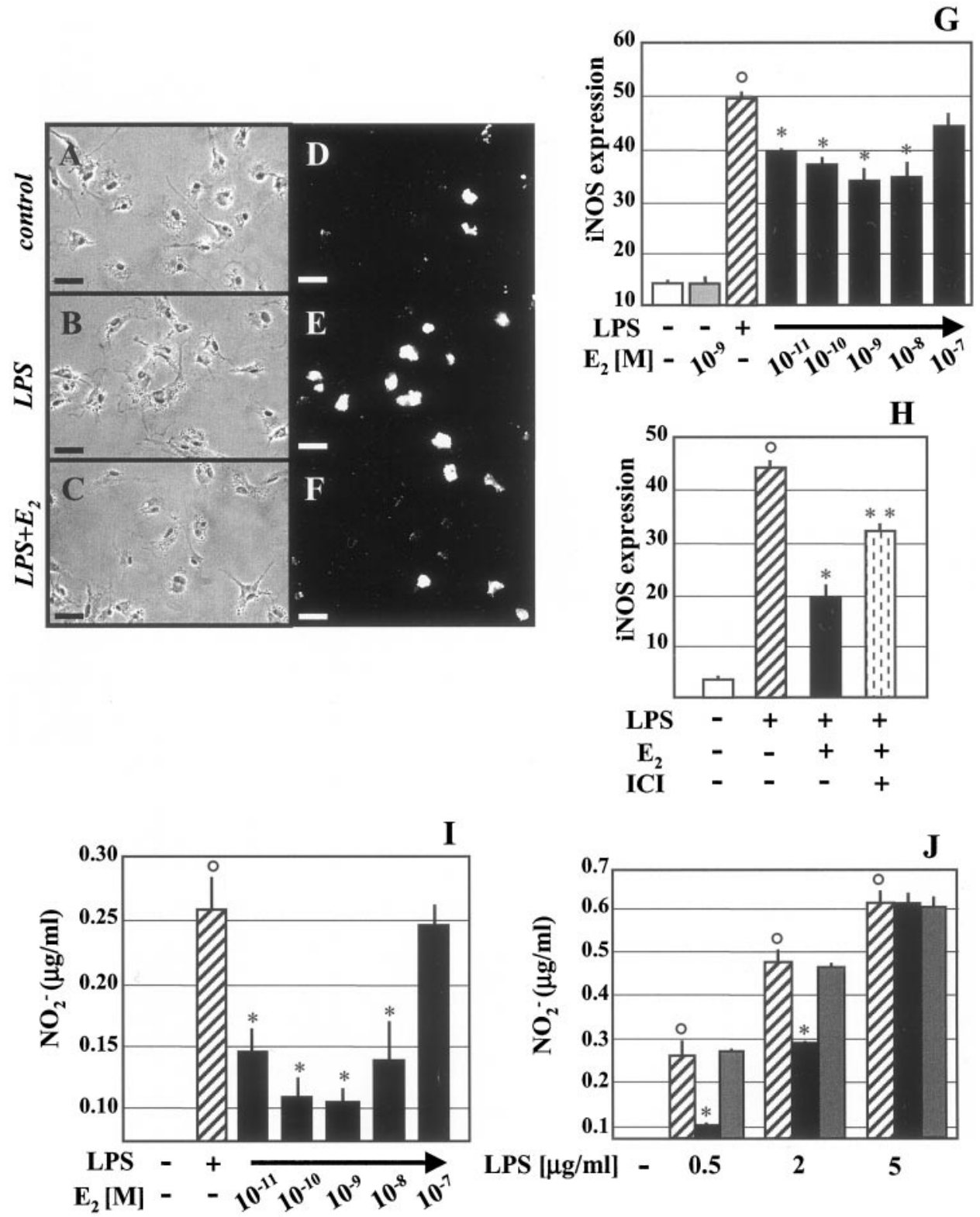

solution (Stratagene, La Jolla, CA), heat-denatured ${ }^{32} \mathrm{P}$-labeled MMP-9 cDNA was added for $1 \mathrm{hr}$ at the same temperature. Membrane was washed in $1 \times$ sodium chloride and sodium phosphate EDTA buffer (SSPE) containing $0.1 \% \mathrm{SDS}$, at $42^{\circ} \mathrm{C}$ for $20 \mathrm{~min}$ and at $50^{\circ} \mathrm{C}$ for $15 \mathrm{~min}$, then at $50^{\circ} \mathrm{C}$ for $15 \mathrm{~min}$ in $0.1 \times \mathrm{SSPE}$ and $0.1 \%$ SDS. The membrane was exposed to autoradiographic film (Hyperfilm; Amersham Pharmacia Biotech) with intensifying screens at $-80^{\circ} \mathrm{C}$ for $24 \mathrm{hr}$.

\section{Transient transfections}

Twenty-four hours before transfection, $2 \times 10^{5}$ cells were plated in 6 well plates containing $3 \mathrm{ml}$ of phenol red-free RPMI 1640 medium supplemented with $10 \%$ DCC-FBS. Six hours before addition of the Ca phosphate-DNA mix, medium was replaced with DMEM with $10 \%$ DCC-FBS. Plasmids 2.2-CAT or 670Xba-CAT (from H. Sato, Keio University, Tokyo, Japan), containing the full-length or a shorter fragment of the human MMP-9 promoter linked to the chloramphenicol acetyltransferase (CAT) were used to transfect SKNBE cells or HeLa cells (data not shown) grown in 6 well plates. Five thousand micrograms of DNA mixes were added to each well, using the carrier DNA (pGEM3z; Promega) to reach the same final DNA concentration in each transfection mix. Sixteen hr after transfection, medium was replaced with phenol red-free RPMI 1640 containing 1\% DCC-FBS, in the presence or absence of hormone and PMA as specified in each figure. Twenty-four hours later the medium was removed, cells were washed three times with PBS, and cell extracts were prepared for CAT-EIA assay, as specified by the manufacturer (Boehringer-Roche). Protein content was measured according to the method of Bradford (1976). The reported CAT activity is calculated by normalizing the CAT levels with the protein content. Each experiment was performed on triplicate samples and repeated at least three times.

\section{Data analysis}

Data are presented as mean \pm SD of triplicate samples and are representative of at least three independently performed experiments. ANOVA analysis was performed to evaluate the statistical significance of differences between experimental groups with the Bonferroni test. Statistical significance was assigned to the level of $p<0.05$.

\section{RESULTS}

\section{Estrogen prevents LPS-induced morphological activation of microglia in culture}

To investigate on the effect of $17 \beta$-estradiol on microglia activation, we used primary cultures of rat microglia. Hormone was added to the cells in the absence or presence of LPS, known to 

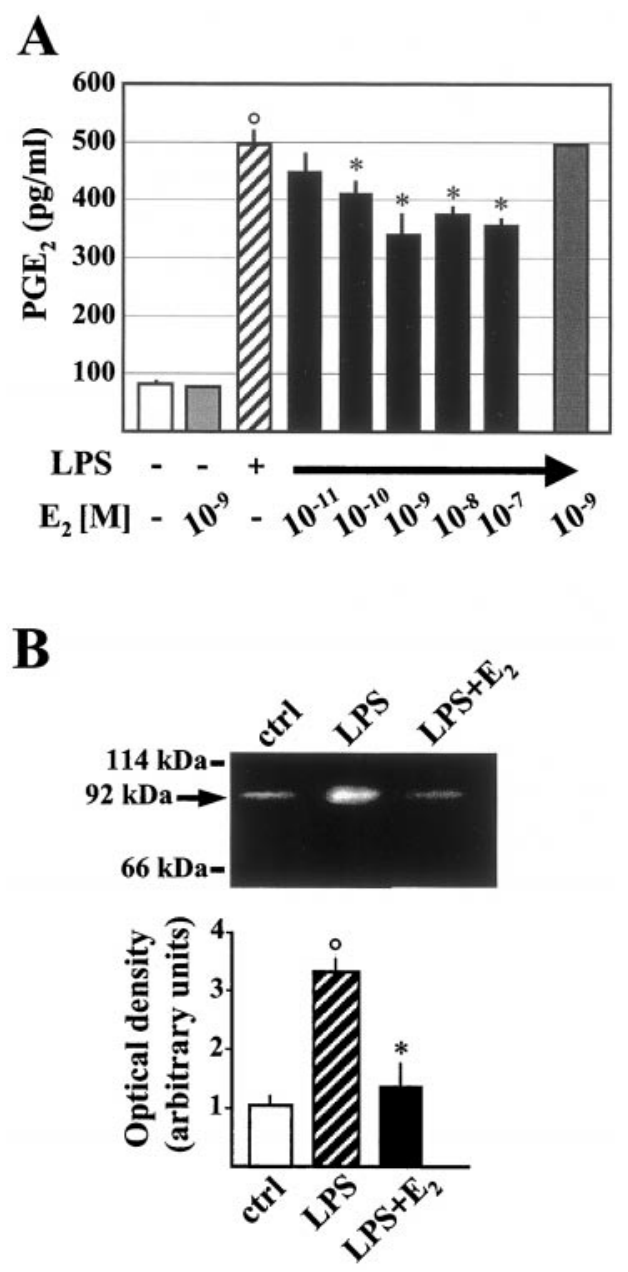

Figure 3. Estrogen attenuates LPS-induced production of $\mathrm{PGE}_{2}$ and gelatinase-B in microglia. Supernatants from primary cultures of rat microglia were collected and analyzed for $\mathrm{PGE}_{2}$ content $(A)$ or gelatinolytic activity $(B)$. Cells were treated in the absence (empty boxes) or presence of molar concentrations of $17 \beta$-estradiol ( $\mathrm{E}_{2}$. light gray boxes), $0.5 \mu \mathrm{g} / \mathrm{ml}$ LPS (dashed boxes), or in the presence of LPS and estrogen added $4 \mathrm{hr}\left(L P S+E_{2}\right.$. black boxes $)$ or simultaneously with the endotoxin (dark gray boxes), as indicated in the graphs. B, A representative zimography, where the numbers to the left indicate the location of the molecular weight markers and of the gelatinolytic activity (MMP-9), and the densitometric evaluation of the bands obtained from three independent experiments in duplicates are reported; values are represented by arbitrary units. ${ }^{\circ} p<0.01$, as compared with the control, and ${ }^{*} p<0.05$, as compared with the LPS-treated values, were calculated by ANOVA test, followed by a Bonferroni analysis.

induce the inflammatory reaction in microglia. Hormone and LPS effects were first assayed by analyzing cell morphology. Primary cultures of microglia stained with the monocyte-specific ED-1 antibody exhibit the ramified morphology typical of the resting state; it is characterized by long secondary and tertiary branched processes arising from a flattened and elongated cell body (Fig. 1A,a). Sparse round-shaped cells are also present: this amoeboid morphology, typical for the phagocytic and activated state, is often induced during the growth procedures of microglia in culture and is present in $5-10 \%$ of the cells. After exposure to LPS $(0.5 \mu \mathrm{g} / \mathrm{ml}$ for $16 \mathrm{hr})$, a significant increase in the number of amoeboid cells is observed (Fig. $1 A, b$ ), similarly to what already reported by other authors (Giulian and Baker, 1986). Interestingly, when the cells are treated with $1 \mathrm{~nm} 17 \beta$-estradiol for $4 \mathrm{hr}$
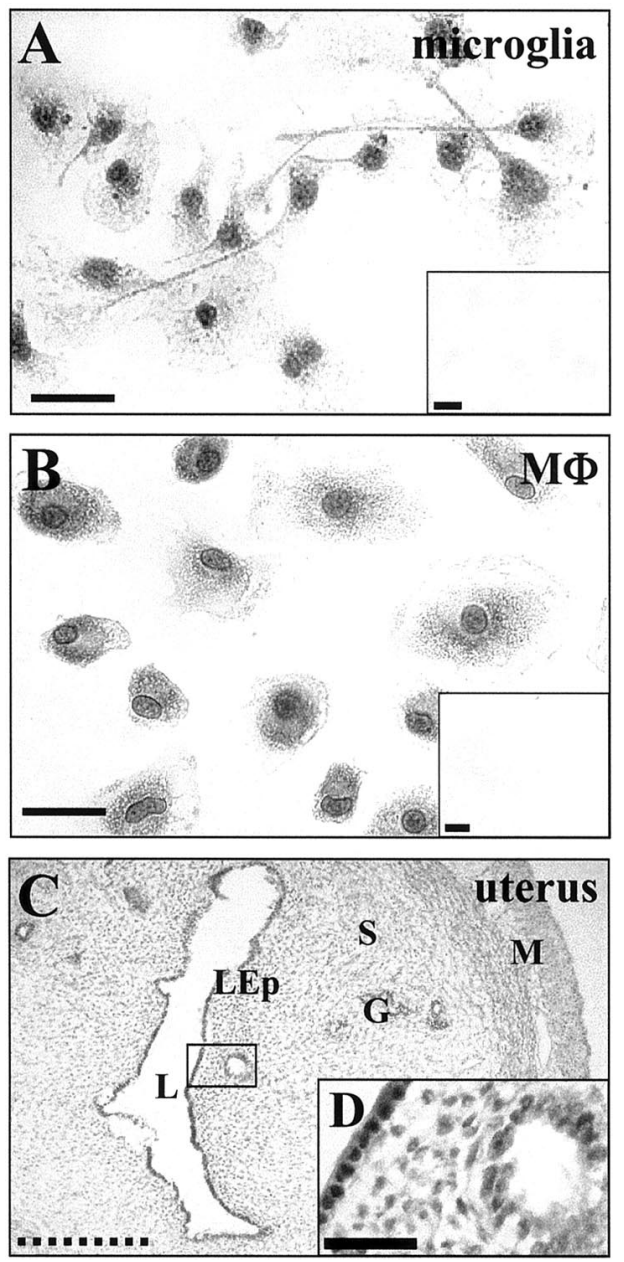

Figure 4. Expression of ER- $\alpha$ and ER- $\beta$ in microglia and macrophages. Direct-light photomicrographs of ER- $\alpha$ immunoreactivity in microglia $(A)$ and macrophages $(\mathrm{M} \Phi ; B)$. The small insets correspond to a parallel immunostaining in which the primary antibody was omitted. $C, \mathrm{ER} \alpha$ distribution in the luminal epithelium $(L E p)$, gland cells $(G)$, stroma $(S)$, and smooth muscle structures $(M)$ of rat uterus. $L$, Lumen. $D$, Magnification of the boxed area in $C$, showing the nuclear localization of the staining. Black bars are $40 \mu \mathrm{m}$, dashed bar is $1 \mathrm{~mm}$, and bar in $D$ is $10 \mu \mathrm{m}$. Photographs were made by using a 990 Coolpix digital photocamera, then visualized and printed using standard computer programs.

before LPS addition, the phenotypic conversion to the activated state is significantly altered (Fig. $1 A, c$ ). Estrogen effect on LPS activation was quantified by counting the cells exhibiting the different morphologies as specified in Materials and Methods. Treatment with $1 \mathrm{~nm} 17 \beta$-estradiol reduced by $70 \%$ the effect of LPS (Fig. $1 B$ ). 17 $\beta$-estradiol protective effect was not observed in the presence of $100 \mathrm{~nm}$ of the specific ER antagonist ICI 182,780. $17 \beta$-estradiol did not influence LPS activity. Treatment with nanomolar concentrations of $17 \beta$-estradiol alone for $20 \mathrm{hr}$ did not modify the cell phenotype (data not shown). These results show that estrogen hinders the morphological phenotype induced by LPS in microglia cells; the effect is not observed with the inactive estrogen $17 \alpha$-estradiol and is blocked by estrogen receptor antagonists suggesting a receptor-mediated effect of the hormone.

\section{Biochemical markers of activated microglia are modulated by estrogen}

We then extended our observation to the study of hormone activity on LPS-induced production of inflammatory mediators. 


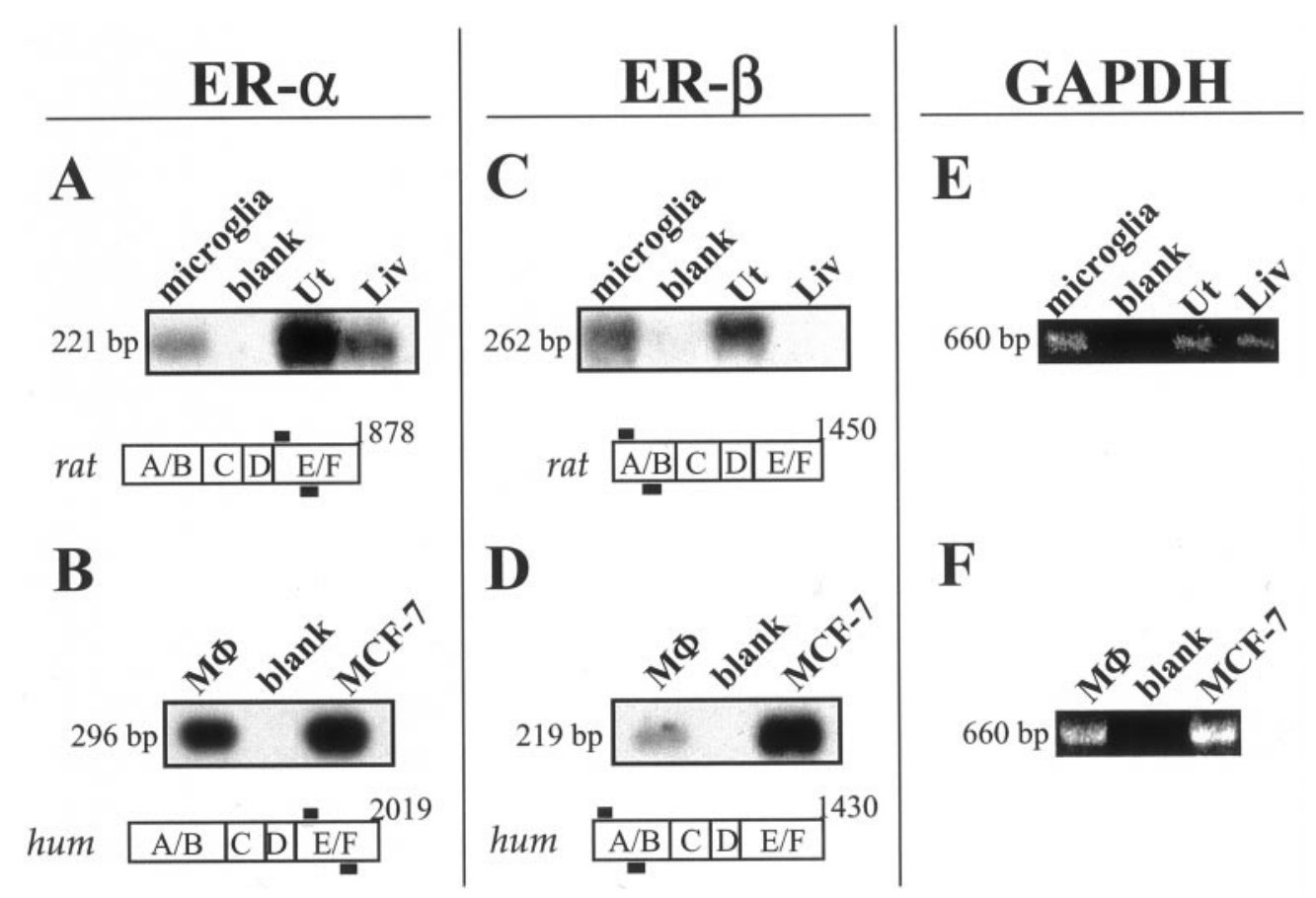

Figure 5. Expression of ER- $\beta$ mRNA in microglia and macrophages. Microglia and macrophage (MФ) ER- $\alpha(A, B)$, ER- $\beta(C, D)$, and GAPDH $(E, F)$ mRNAs were assayed by RT-PCR, followed by Southern blot analysis $(A-D)$. The annealing site of the PCR primers are reported as black boxes with the representation of the respective rat and human (hum) cDNAs; the length of the amplification products are reported on the left of each panel. Rat uterus $(U t)$, liver (Liv), MCF-7 cells, or negative controls (blank, in which microglia or macrophage RNAs were assayed without adding the RT enzyme) were also analyzed. Hybridized membranes were exposed to autoradiographic films for $1 \mathrm{hr}(A, B)$ or $3 \mathrm{hr}(C, D)$ at room temperature. $E, F$, Photographs of the GAPDH amplification products on ethidium bromidestained gels.
Immunostaining of microglia with an anti-iNOS antibody reveals that a small percentage of unstimulated cells expresses this enzyme (Fig. 2A,D); treatment for $16 \mathrm{hr}$ with $0.5 \mu \mathrm{g} / \mathrm{ml} \mathrm{LPS}$ significantly increases iNOS expression (Fig. $2 B, E$ ). Interestingly, treatment with $17 \beta$-estradiol $4 \mathrm{hr}$ before LPS addition results in a significant decrease in iNOS-positive cells in comparison with LPS-treated microglia (Fig. 2C,F). A semiquantitative assessment of the hormonal effect was made by counting the number of total cells under a phase-contrast light and, under fluorescent emission, the number of iNOS-positively stained cells (Fig. 2G). Fifteen percent of unstimulated cells express iNOS; this percentage is increased up to $50 \%$ after LPS addition. Pretreatment with increasing concentrations of $17 \beta$-estradiol reduces iNOS-positive cells, as compared with LPS. This effect is proportional with the concentration of hormone used: a significant decrease $(-28 \%)$ is observed with $17 \beta$-estradiol as low as $0.01 \mathrm{~nm}$, whereas the maximal effect $(-43 \%)$ is observed with $1 \mathrm{~nm}$ hormone. Very high concentrations of estrogen (100 nM) are less efficacious, in line with previous observations in ours and in other laboratories. Hormone alone does not modify iNOS synthesis as compared with control levels.

One hundred nanomolar ICI 182,780 blocked $17 \beta$-estradiol effects on iNOS expression induced by LPS (Fig. $2 H$ ).

To assess whether the alteration in iNOS content was paralleled by a modification in the enzyme activity, we evaluated the $\mathrm{NO}_{2}{ }^{-}$ levels in cell culture medium. As shown in Figure $2 \mathrm{I}, \mathrm{NO}_{2}$ concentration from untreated cells is below the levels of detection; according to the immunocytochemistry results, treatment with $17 \beta$-estradiol prevents the LPS-induced accumulation of $\mathrm{NO}_{2}{ }^{-}$in a dose-dependent manner. In the experiments described above, estrogen was added $4 \mathrm{hr}$ before $0.5 \mu \mathrm{g} / \mathrm{ml}$ of LPS. We then asked whether the hormonal effect on iNOS activity could still be observed if the hormone was added at the same time as LPS or when higher concentrations of LPS were used. We therefore compared $\mathrm{NO}_{2}{ }^{-}$secretion in cells exposed to estrogen at the same time or $4 \mathrm{hr}$ before LPS; the bacterial endotoxin was assayed at the concentration of $0.5,2$, and $5 \mu \mathrm{g} / \mathrm{ml}$. As shown in
Figure $2 \mathrm{~J}, \mathrm{NO}_{2}{ }^{-}$accumulation in microglia culture medium is proportional with the concentration of LPS used, being maximal at $5 \mu \mathrm{g} / \mathrm{ml}$ of LPS. The $\mathrm{NO}_{2}{ }^{-}$increase is not prevented by estrogen when LPS and hormone are added at the same time, or when the cells are incubated with estrogen for $4 \mathrm{hr}$ before the highest concentration of LPS $(5 \mu \mathrm{g} / \mathrm{ml})$. These results indicate that a specific intensity of the LPS-activated signaling cascade is critical to hormone action on microglial iNOS expression and activity. The necessity of a correct timing in hormone-LPS treatment suggested by the observation of the hormone effect on iNOS activity (Fig. 2J) is further supported by analysis of the number of LPS-activated cells in the absence or presence of $17 \beta$-estradiol. Figure $1 C$ shows that the blockade of LPS action is maximal when the hormone is added $4 \mathrm{hr}$ before LPS. When the time interval between the two treatments is $\leq 30 \mathrm{~min}$, no protection is observed.

We next examined whether the activity of estrogen against LPS could be extended to other LPS-inducible inflammatory mediators, such as $\mathrm{PGE}_{2}$, known to sustain local and systemic inflammatory responses (Janabi et al., 1996; Minghetti et al., 1996). As shown in Figure $3 A, 0.5 \mu \mathrm{g} / \mathrm{ml}$ LPS induced a significant increase in $\mathrm{PGE}_{2}$ production. This effect is progressively blocked by $4 \mathrm{hr}$ pretreatment of microglial cells with increasing concentrations of estrogen, but not present when LPS and $17 \beta$-estradiol are added simultaneously. The effect is significant $(-25 \%)$ when the hormone is used at the final concentration of $0.1 \mathrm{~nm}$ and maximal at $1 \mathrm{~nm}(-43 \%)$. Again, hormone does not modify $\mathrm{PGE}_{2}$ production when added alone, or at the same time as $0.5 \mu \mathrm{g} / \mathrm{ml}$ of LPS or 4 $\mathrm{hr}$ before $5 \mu \mathrm{g} / \mathrm{ml}$ of the bacterial endotoxin (data not shown).

These data show that estrogen blocks $\mathrm{PGE}_{2}$ synthesis induced by LPS in microglia, demonstrating for the first time that the hormone is able to interfere with the synthesis of this AA metabolite.

Because it is known that tissue degradation by metalloproteases is pivotal to inflammation, we tested the effect of estrogen on microglial production of MMP-9. As shown in Figure $3 B$, treatment with $0.5 \mu \mathrm{g} / \mathrm{ml}$ LPS for $16 \mathrm{hr}$ stimulated a $92 \mathrm{kDa}$ 

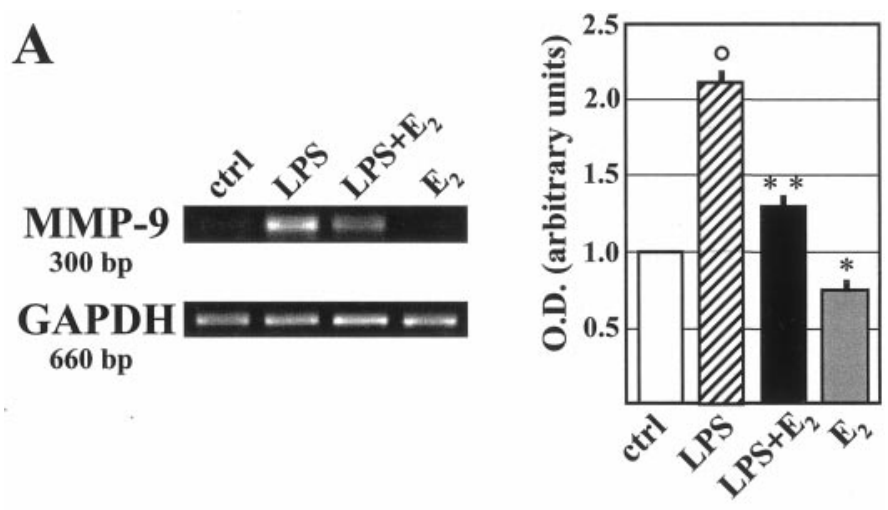

B
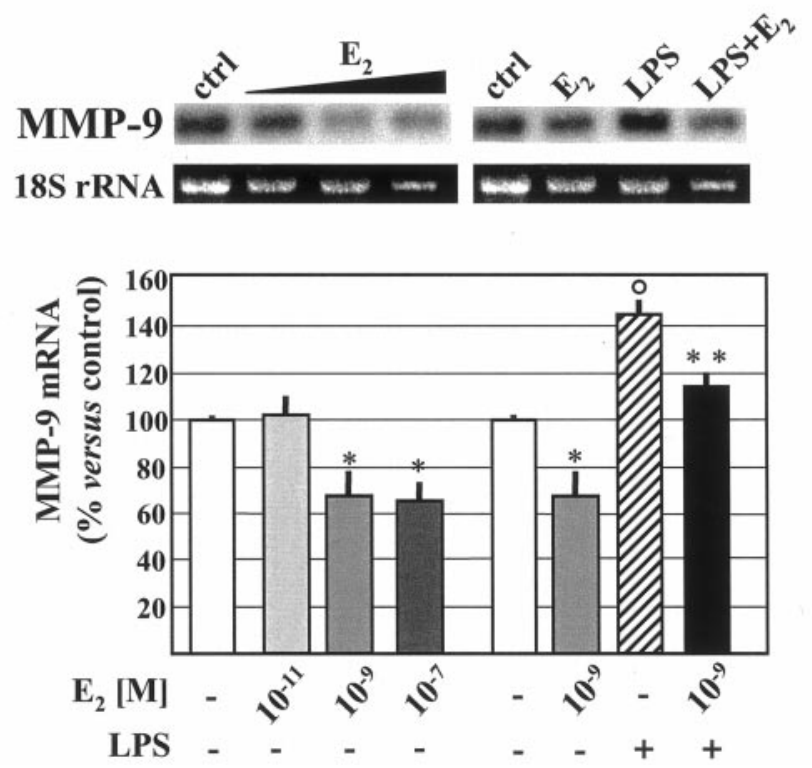

Figure 6. MMP-9 mRNA content is regulated by estrogen in microglia and macrophages. A, Microglia MMP-9 and GAPDH mRNAs were assayed by RT-PCR. Photographs of the amplification products separated on ethidium bromide-stained agarose gels are reported together with the length of the amplification products reported on the left. A quantitative assessment of the intensity of the bands is reported in the graph on the right and represents the mean $\pm \mathrm{SD}$ of three separate experiments. $B, \mathrm{~A}$ representative Northern blot analysis showing the $2.8 \mathrm{~kb}$ human MMP-9 mRNA and the 18S ribosomal RNA ( $r R N A$ ) loaded on the gel. The densitometric evaluation of the bands obtained from three independent experiments is represented in the bottom part of $B$; values are represented as percentage in respect to control values and are calculated as the mean $\pm \mathrm{SD}$. Cells were treated in the absence (empty boxes) or presence of increasing molar concentrations of $17 \beta$-estradiol $\left(E_{2}\right)$ (light gray to dark gray boxes), $0.5 \mu \mathrm{g} / \mathrm{ml}$ LPS (dashed boxes), or in the presence of both LPS and estrogen (LPS $+E_{2}$; black boxes), as indicated in the graphs. ${ }^{\circ} p<$ 0.01 , as compared with the control, ${ }^{*} p<0.05$, as compared with the control values, and ${ }^{* *} p<0.05$, as compared with LPS values, were calculated by ANOVA test, followed by a Bonferroni analysis.

gelatinase activity, as already reported (Gottshall et al., 1995); this induction is significantly reduced by nanomolar concentrations of $17 \beta$-estradiol added to the cells $4 \mathrm{hr}$ before LPS. The 92 $\mathrm{kDa}$ gelatinase activity present in the conditioned medium of LPS-stimulated cells comigrates with rat MMP-9, as assessed by Western blot (data not shown), suggesting that the gelatinolytic activity corresponds to MMP-9. These results show that the hormone is able to reduce the gelatinolytic activity of microglia induced by a proinflammatory stimulus. This hormonal effect had never been described before in inflammatory cells and might represent a proper hint to the study of the degradative process leading to tissue destruction (Birkedal-Hansen, 1993).

\section{Microglia and macrophages express ER $\alpha$ and ER $\beta$}

The above results demonstrate that estrogen modifies the morphological changes and the production of inflammatory mediators induced by LPS in microglia, suggesting an anti-inflammatory activity for the hormone in these cells. To evaluate whether this activity involves a direct effect of the hormone on gene transcription, we first investigated whether microglia express the ERs. Figure $4 A$ shows the positive nuclear staining of $\mathrm{ER} \alpha$ protein in microglial cells using the ER-21 anti-rat ER $\alpha$ antibody. The specificity of this interaction is confirmed by the lack of signal in reactions in which the primary antibody is omitted (Fig. 4A, insert) and by the signal distribution in rat uterine tissue (Fig. $4 C, D)$. In addition, we extended the evaluation on ER- $\alpha$ expression also to primary cultures of monocytes-derived macrophages (Fig. $4 B$ ). Approximately $90 \%$ of cells were ER $\alpha$-positive in both reactive and resting microglia and macrophages.

The lack of a reliable and specific antibody to recognize ER- $\beta$ does not allow to assay for receptor protein expression; we performed an RT-PCR assay to detect ER- $\alpha$ and ER- $\beta$ mRNA expression in both microglia and macrophage cells (Fig. 5). The specificity of the PCR reactions for each receptor isoform in human and rat cell extracts was confirmed by Southern blot analysis and by comparing the size of the amplification products with that from ER-positive tissues and cell lines. With this experiment we were able to show that microglia and macrophages express ER- $\alpha$ and ER- $\beta$ mRNAs (Fig. $5 A-D$ ). By comparing the levels of the two receptor products with that of GAPDH, a housekeeping gene, we could speculate that ER- $\alpha$ and ER- $\beta$ mRNAs are present at similar levels in microglia, whereas in human macrophages ER- $\alpha$ is the predominant isoform.

Altogether, these data show that microglia and macrophages express the ER- $\alpha$ and ER- $\beta$.

\section{LPS-induced MMP-9 expression is blocked by ER $\alpha$ activation}

The presence of ERs in microglia and macrophages suggests that the downmodulation of inflammatory mediators observed after estrogen treatment may occur at the transcriptional level. We therefore investigated on MMP-9 mRNA accumulation after estrogen and LPS in macrophages and microglia. The study was done by Northern blot in human macrophage and by RT-PCR in microglia. Macrophages express MMP-9 mRNA, as already reported by $\mathrm{Xu}$ et al. (1999); we show here that microglia also express this protein. In macrophages, a $5 \mathrm{hr}$ incubation with increasing concentrations of $17 \beta$-estradiol results in a significant decrease in MMP-9 mRNA content, the maximal reduction $(-40 \%)$ is observed using $1 \mathrm{~nm} 17 \beta$-estradiol (Fig. $6 B$ ). When the cells are stimulated with LPS, MMP-9 mRNA is increased by $50 \%$; this induction is significantly reduced after estrogen addition. In microglia LPS increases MMP-9 mRNA, and $17 \beta-$ estradiol blocks this effect (Fig. 6A). When estrogen is added alone, a $30 \%$ reduction in MMP-9 mRNA is observed.

We further investigated hormone action on MMP-9 expression by assaying ER- $\alpha$ activity on MMP-9 promoter transcription in transient transfection assays. ER $\alpha$-negative cells of neural origin (SK-N-BE) were transfected with a reporter plasmid containing a $2200 \mathrm{bp}$ fragment of the human MMP-9 promoter in the absence or presence of an ER $\alpha$ expression vector (Fig. 7A). Basal transcription from this promoter is very low, and it is strongly induced by 
Figure 7. MMP-9 promoter activity is modulated by ER- $\alpha$. ER-negative SK-N-BE cells were transiently transfected with the $2200 \mathrm{bp}(A)$ or $670 \mathrm{bp}$ $(B)$ fragments of the hMMP-9 promoter, in the absence or presence of hER- $\alpha$ expression vector. Cells were treated with $10 \mathrm{~nm}$ PMA and/or $10 \mathrm{~nm}$ $17 \beta$-estradiol $\left(E_{2}\right)$, as specified above each figure. In $B, 0.01,0.1,1$, and 10 nM $17 \beta$-estradiol were assayed. The reported promoter activity is calculated by normalizing the CAT level with protein content and represents the mean $\pm \mathrm{SD}$ of triplicate determinations, representative of at least three separate experiments. ${ }^{\circ} p<0.01$, as compared with the control, i.e., untreated cells without transfected ER- $\alpha,{ }^{*} p<0.05$, as compared with the LPS value of the same experimental group, and $* p<0.05$, as compared with ER- $\alpha$-transfected cells without treatment, were calculated by ANOVA test, followed by a Bonferroni analysis.

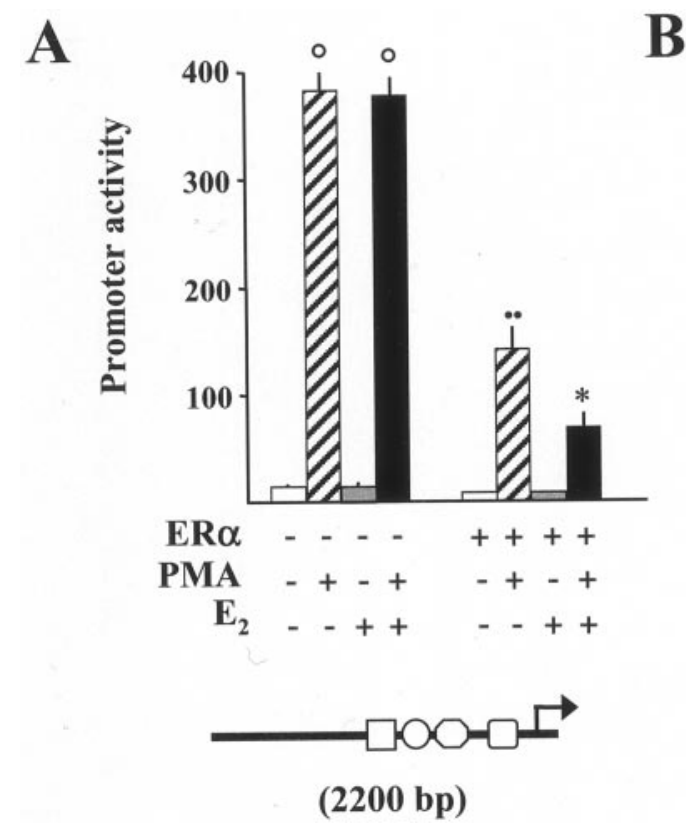

B

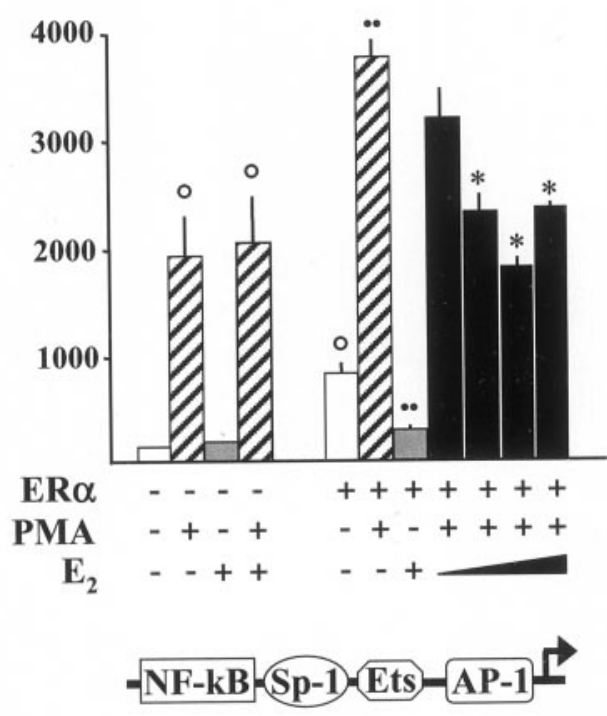

(670 bp)
PMA. Estrogen addition does not modify the promoter activity in the absence of cotransfected receptor. When $\mathrm{ER} \alpha$ is added to the transfection mixture, $1 \mathrm{nM} 17 \beta$-estradiol blocks PMA induction by $50 \%$. By using the proximal fragment of the MMP-9 promoter $(670$ bp), we were able to better evaluate the estrogen activity (Fig. $7 B$ ). In fact, the $670 \mathrm{bp}$ promoter has a higher basal transcription and shows better induction by PMA (eightfold). With this promoter, a dose-dependent effect of hormone-mediated reduction in PMAstimulated transcription is observed (Fig. 7B); $1 \mathrm{~nm} 17 \beta$-estradiol causes the maximal $50 \%$ reduction. Using the shorter promoter, estrogen-activated ER- $\alpha$ in the absence of PMA is able to reduce the basal transcriptional levels by $60 \%$.

These results show that, when activated by its cognate hormone, ER- $\alpha$ is able to reduce basal and PMA-activated transcription of MMP-9 promoter. Similar results were obtained by transfections in HeLa cells (data not shown), suggesting a common mechanism for ER- $\alpha$ regulation of MMP-9 transcription in different cell types. The unliganded receptor alters the extent of PMA induction (Fig. 7A) and the basal transcription of the $670 \mathrm{bp}$ promoter (Fig. $7 B$ ). These effects have already been reported in transfections studies with steroid receptors and have been ascribed to the cross-talk between ERs and membrane receptors activated by serum components (Patrone et al., 2000).

Altogether, these results demonstrate that estrogen regulates MMP-9 promoter activity; this mechanism might therefore be responsible, at least in part, for the reduction in MMP-9 mRNA levels detected after estrogen treatment of macrophage cells.

\section{DISCUSSION}

In this report we demonstrate that $17 \beta$-estradiol prevents microglia activation: we show that this hormone inhibits the morphological conversion toward a reactive phenotype and hinders the LPS-induced production of mediators involved in the inflammatory process, like NO and iNOS, $\mathrm{PGE}_{2}$, and MMP-9. Our findings are in agreement with previous observations reported by this and other laboratories, which demonstrated that, in different cell types, estrogen blocks iNOS expression induced by inflammatory stimuli (Hayashi et al., 1998; Zancan et al., 1999). An estrogen- induced reduction of MMP-9 synthesis has been only demonstrated in the parenchymal cells of the endometrium (Marbaix et al., 1996). Similarly, whereas Kawaguchi et al. (1995) has already shown that estrogen inhibits bone marrow production of prostaglandin stimulating factors, this is the first report demonstrating an effect of estrogen on $\mathrm{PGE}_{2}$ levels.

Overexpression of these inflammatory-related factors has been reported at the histopathological sites of brain neurodegenerative diseases associated with a chronic inflammatory process. Nitric oxide activity has been correlated with the progressive degeneration of neural cells and with the activation and migration of microglia at the lesion site (Dawson et al., 1991; Boje and Arora, 1992; Chao et al., 1992; Meda et al., 1995). On the other hand, MMP-9 is involved in the destruction of the basal membrane (Johnson et al., 1998) and degradation of proteins, such as plasminogen activator or $\beta$-amyloid, whose activity has been correlated with the progression of neurodegeneration (Deb and Gottschall, 1996; Gottshall, 1996). $\mathrm{PGE}_{2}$ has since long been related with inflammation in different tissues; recently, cyclooxygenase metabolites have been involved in CNS inflammatory reactions as well as in brain ischemia processes (Buccellati et al., 1998), providing insight into the onset mechanisms and suggesting novel therapeutic interventions for brain inflammationrelated diseases (Kalaria, 1999).

Beneficial effects of estrogen on neurodegeneration have been correlated with various mechanisms triggered by the hormone directly on neurons: (1) increase in neurotransmission and synaptic connections (Gibbs et al., 1997; Gibbs, 1999, Beyer and Karolczak, 2000); (2) prevention of neuronal apoptosis (Toran Allerand et al., 1999); (3) regulation of mitochondrial activity (Bettini and Maggi, 1992); and (4) inhibition of specific proteases that would lead to the production of pathogenic peptides, such as $\beta$-amyloid (Shi et al., 1998).

Our results support a novel hypothesis for estrogen action in the CNS: together with a direct neurotrophic and antiapoptotic effect on neurons, estrogen might preserve the functional and structural integrity of the brain by quenching the inflammatory response associated with neurodegeneration. 
Interestingly, we observed that a correct timing and concentration in hormone and LPS treatments are necessary to observe the effects reported in this paper, revealing that estrogen is inactive when the inflammatory reaction is already ongoing. This could imply that, in vivo, estrogen is effective only when the inflammatory process may be controlled, that is, at the early stage of the development of inflammation-associated diseases. This is in line with the results of recent clinical trials, which indicated that estrogen replacement therapy does not improve memory or intellectual functions of women affected by mild to moderate AD (Mulnard et al., 2000), whereas it delays disease onset when administered in healthy perimenopausal women (Honjo et al., 1995; Tang et al., 1996; Kawas et al., 1997).

The anti-inflammatory activity of estrogen might also be relevant in the pathogenesis of other inflammation-associated diseases, like osteoporosis, vasculites, and atherosclerosis, in which overproduction or defective regulation of the inflammatory components and a beneficial role for estrogen have been recognized (Horowits, 1993; Nathan and Chadhuri, 1997). Indeed, estrogenregulated pathways have been identified in monocytes and macrophages (Olsen and Kovacs, 1996). Transcription of genes regulating cell adhesion (Frazier-Jessen and Kovacs, 1995), tissue remodeling (Marbaix et al., 1996), oxidative state (Hayashi et al., 1998), survival (Vegeto et al., 1999), and inflammatory response (Polan et al., 1989; Fox et al., 1991; McLaren et al., 1996; Deshpande et al., 1997) has been shown to be modulated by estrogen. Our present demonstration of ER expression and activity in macrophage cells strongly supports this view.

With regard to the mechanism of action of estrogen on the inflammatory mediators, our data are suggestive of a receptormediated genomic control: (1) estrogen exerts its activity at concentrations compatible with receptor activation. (2) Estrogen activity is blocked by the receptor antagonist ICI 182,780, and when the time interval between hormone and LPS treatments is $<60 \mathrm{~min}$, (3) ER- $\alpha$ and ER- $\beta$ are expressed in microglia and monocyte-derived macrophages. (4) Estrogen downregulates MMP-9 mRNA levels in microglia and macrophages. (5) Estrogen-activated ER- $\alpha$ blocks MMP-9 promoter induction. Extensive studies using MMP-9 promoter deletions and mutations had revealed that different DNA elements, corresponding to the binding sites for AP-1, NF-kB, Sp-1, and Ets transcription factors mediate induction of MMP-9 transcription by different agents (Sato and Seiki, 1993; Bond et al., 1998), as reported in Figure 7B. However, no sequence reminiscent of an ERE can be found in this promoter. Thus, it is unlikely that the hormone-receptor complex directly associates with this promoter. However, our transfection studies clearly show that, in the absence of ER- $\alpha$, estrogen does not modify MMP-9 promoter activity. A cross-talk among the ER and membrane-associated signaling pathways modifies the promoter activity of different genes, whose products are involved in monocyte-macrophage physiology (Galien and Garcia, 1997); we hypothesize that this interaction underlies the mechanism of estrogen blockage of MMP-9 promoter. This is in line with other reports, which showed that expression of different MMPs is inhibited by ligands of the nuclear receptor superfamily, such as retinoids, glucocorticoids, androgens, and progestins (Schroen and Brinckerhoff, 1996a), although few consensus hormone responsive elements are present in the promoters. It has been proposed that these hormones regulate MMP transcription by binding the Jun/Fos complex and blocking their transcriptional activity at the AP-1 sites (Jonat et al., 1990; Schroen and Brinckerhoff, 1996b). However, the androgen receptor negatively regulates MMP-1 transcription through the interaction with Etsrelated transcription factors (Schneikert et al., 1996).

Estrogen action on microglia has only been recently hypothesized (Mor et al., 1999). Our study demonstrates a role for this hormone in brain inflammatory pathways and extends our knowledge on estrogen action in the CNS. By identifying novel molecular and cellular targets for hormone action, our results might be relevant for the screening of ER ligands to be used in the prevention of neurodegenerative diseases.

\section{REFERENCES}

Adamson DC, Wildemann B, Sasaki M, Glass JD, McArthur JC, Christov VI, Dawson TM, Dawson VL (1996) Immunologic NO synthase: elevation in severe AIDS dementia and induction by HIV-a gp41. Science 274:1917-1921.

Bagasra O, Michaels FH, Sheng YM, Borroski LE, Spitsin SV, Fu ZF, Tawadros R, Koprowski H (1995) Activation of the inducible form of nitric oxide synthase in the brains of patients with multiple sclerosis. Proc Natl Acad Sci USA 92:12041-12045.

Bettini E, Maggi A (1992) Estrogen induction of cytochrome c oxidase subunit III in rat hippocampus. J Neurochem 58:1923-1929.

Beyer C, Karolczak M (2000) Estrogenic stimulation of neurite growth in midbrain dopaminergic neurons depends o cAMP/protein kinase-A signaling. J Neurosci Res 59:107-116.

Bo L, Dawson TM, Wesselingh S, Mork S, Choi S, Kong PA, Hanley D, Trapp BD (1994) Induction of nitric synthase in demyelinating regions of multiple sclerosis brains. Ann Neurol 36:778-786.

Boje KM, Arora PK (1992) Microglial-produced nitric oxide and reactive nitrogen oxides mediate neuronal cell death. Brain Res 587:250-256.

Bond M, Fabunmi P, Baker AH, Newby AC (1998) Synergistic upregulation of metalloproteinase-9 by growth factors and inflammatory cytokines: an absolute requirements for transcription factor NF-kB. FEBS Lett 435:29-34.

Bradford MM (1976) A rapid and sensitive method for the quantitation of microgram quantities of protein utilizing the principle of protein-dye binding. Anal Biochem 72:248-254.

Brikedal-Hansen H (1993) Role of cytokines and inflammatory mediators in tissue destruction. J Periodont Res 28:500-510.

Buccellati C, Folco GC, Sala A, Scelsi R, Masoero E, Poggi P, Govoni S, Favalli L, Rozza A (1998) Inhibition of prostanoid synthesis protects against neuronal damage induced by focal ischemia in rat brain. Neurosci Lett 257:123-126.

Chao CC, Hu S, Molitor TW, Shaskan EG, Peterson PK (1992) Activated microglia mediate neuronal cell death injury via a nitric oxide mechanism. J Immunol 149:2736-2741.

Chomczynski P, Sacchi N (1987) Single-step method for RNA isolation by acid guanidinium thiocyanate-phenol-chloroform extraction. Anal Biochem 162:156-159.

Cuzzocrea S, Santagati S, Sautebin L, Mazzon E, Calabro G, Serraino I, Caputi AP, Maggi A (2000) 17beta-estradiol antiinflammatory activity in carrageenan-induced pleurisy. Endocrinology 141:1455-1463.

Dawson VL, Dawson TM, London ED, Bredt DS, Snyder SH (1991) Nitric oxide mediates glutamate neurotoxicity in primary cortical cultures. Proc Natl Acad Sci USA 88:6368-6371.

Deb S, Gottschall PE (1996) Increased production of matrix metalloproteinases in enriched astrocyte and mixed hippocampal cultures treated with beta-amyloid peptides. J Neurochem 66:1641-1647.

Deshpande R, Khalili H, Pergolizzi RG, Michael SD, Chang M-dY (1997) Estradiol down-regulates LPS-induced cytokine production and NFkB activation in murine macrophages. Am J Reprod Immunol 38:46-54.

Fox HS, Bond BL, Parslow TG (1991) Estrogen regulates the IFNgamma promoter. J Immunol 146:4362-4367.

Frazier-Jessen MR, Kovacs EJ (1995) Estrogen modulation of JE/ monocyte chemoattractant protein-1 mRNA expression in murine macrophages. J Immunol 154:1838-1845.

Galien R, Garcia T (1997) Estrogen receptor impairs interleukin-6 expression by preventing protein binding on the NF-kB site. Nucleic Acids Res 25:2424-2429.

Gibbs RB (1999) Treatment with estrogen and progesterone affects relative levels of brain-derived neurotrophic factor mRNA and protein in different regions of the adult rat brain. Brain Res 844:20-27.

Gibbs RB, Hashash A, Johnson DA (1997) Effects of estrogen on potassium-stimulated acetylcholine release in the hippocampus and overlying cortex of adult rats. Brain Res 749:143-146.

Giulian D, Baker TJ (1986) Characterization of ameboid microglia isolated from developing mammalian brain. J Neurosci 6:2163-2178.

Gonzalez-Scarano F, Baltuch G (1999) Microglia as mediators of inflammatory and degenerative diseases. Annu Rev Neurosci 22:219-240. 
Gottshall PE (1996) Beta-amyloid induction of gelatinase B secretion in cultured microglia: inhibition by dexamethasone and indomethacin. NeuroReport 7:3077-3080.

Gottshall PE, Yu X, Bing B (1995) Increased production of gelatinase B (matrix metalloproteinase- 9 ) and interleukin- 6 by activated rat microglia in culture. J Neurosci Res 42:335-342.

Gu Q, Moss RL (1996) 17beta-estradiol potentiated kainate-induced currents via activation of the cAMP cascade. J Neurosci 16:3740-3744.

Hayashi T, Yamada K, Aesaki T, Muto E, Chaudhuri G, Iguchi A (1998) Physiological concentrations of $17 \beta$-estradiol inhibit the synthesis of nitric oxide synthase in macrophages via a receptor-mediated system. J Cardiovasc Pharmacol 31:292-298.

Honjo H, Tanaka K, Kashiwagi T, Urabe M, Okada H, Hayashi M, Hayashi K (1995) Senile dementia-Alzheimer's type and estrogen. Hormone Metab Res 27:204-207.

Horowits MC (1993) Cytokines and estrogen in bone: antiosteoporotic effects. Science 260:626-627.

Janabi N, Chabrier S, Tardieu M (1996) Endogenous nitric oxide activates prostaglandin $\mathrm{F} 2$ alpha production in human microglial cells but not in astrocytes: a study of interactions between eicosanoids, nitric oxide, and superoxide anion $\left(\mathrm{O}_{2}^{-}\right)$regulatory pathways. J Immunol 157:2129-2135.

Johnson LL, Dyer R, Hupe DJ (1998) Matrix metalloproteinases. Curr Opin Chem Biol 2:466-471.

Jonat C, Rahmsdorf HJ, Park KK, Cato AC, Gebel S, Ponta H, Herrlich $P$ (1990) Antitumor promotion and antiinflammation: downmodulation of AP-1 (Fos/Jun) activity by gluococorticoid hormone. Cell 62:1189-1204.

Kalaria RN (1999) Microglia and Alzheimer's disease. Curr Opin Hematol 6:15-24.

Katzenellenbogen JA, O'Malley BW, Katzenellenbogen BS (1996) Tripartite steroid hormone receptor pharmacology: interaction with multiple effector site for the cell-and promoter-specific action of these hormones. Mol Endocrinol 10:119-131.

Kawaguchi H, Pilbeam CC, Vargas SJ, Morse EE, Lorenzo JA, Raisz LG (1995) Ovariectomy enhances and estrogen replacement inhibits the activity of bone marrow factors that stimulate prostaglandin production in cultured mouse calvariae. J Clin Invest 96:539-548.

Kawas C, Resnick S, Morrison A, Brookmeyer R, Corrada M, Zonderman A, Bacal C, Lingle DD, Metter E (1997) A prospective study of estrogen replacement therapy and the risk of developing Alzheimer's disease: the Baltimore Longitudinal Study of Aging. Neurology 48:1517-1521.

Kreutzberg GW (1996) Microglia: a sensor for pathological events in the CNS. Trends Pharmacol Sci 8:312-318.

Kuiper GI, Enmark E, Pelto-Hukko M, Gustafsson JÅ (1996) Cloning of a novel estrogen receptor expressed in rat prostate and ovary. Proc Natl Acad Sci USA 93:5925-5930.

Liberatore GT, Jackson-Lewis V, Vukosavic S, Mandir AS, Vila M, McAuliffe WG, Dawson VL, Dawson TM, Przedborski S (1999) Inducible nitric oxide synthase stimulates dopaminergic neurodegeneration in the MPTP model of Parkinson disease. Nat Med 5:1403-1409.

Marbaix E, Kokorine I, Moulin P, Donnez J, Eeckhout Y, Courtoy PJ (1996) Menstrual breakdown of human endometrium can be mimicked in vitro and is selectively and reversibly blocked by inhibitors of matrix metalloproteinase. Proc Natl Acad Sci USA 9:9120-9125.

Matrisian LM (1999) Cancer biology: extracellular proteinases in malignancy. Curr Biol 9:R776-778.

Mc Geer PL, McGeer EG (1996) Anti-inflammatory drugs in the fight against Alzheimer's diseases. Ann NY Acad Sci 777:213-220.

McKay LI, Cidlowsky JA (1999) Molecular control of immune/inflammatory responses: interactions between nuclear factor-kB and steroid receptor-signaling pathways. Endocr Rev 20:435-459.

McLaren J, Prentice A, Charnock-Jones DS, Millican SA, Mueller KH, Sharkey AM, Smith SK (1996) Vascular endothelial growth factor is produced by peritoneal fluid macrophages in endometriosis and is regulated by ovarian steroids. J Clin Invest 98:482-489.

Meda L, Cassatella MA, Szendrel GI, Otvos Jr L, Baron P, Villalba M, Ferrari D, Rossi F (1995) Activation of microglial cells by $\beta$-amyloid protein and interferon-gamma. Nature 374:647-650.

Minghetti L, Polazzi E Nicolini A Creminon C, Levi G (1996) Interferon-gamma and nitric oxide down-regulate lipopolysaccharideinduced prostanoid production in cultured rat microglia cells by inhibiting cyclooxygenase-2 expression. J Neurochem 66:1963-1970.

Mor G, Nilsen J, Horvath T, Bechmann I, Brown S, Garcia-Segura LM,
Naftolin F (1999) Estrogen and microglia: a regulatory system that affects the brain. J Neurobiol 40:484-496.

Mulnard RA, Cotman CW, Kawas C, van Dyck CH, Sano M, Doody R, Koss E, Pfeiffer E, Jin S, Gamst A, Grundman M, Thomas R, Thal LJ (2000) Estrogen replacement therapy for the treatment of mild to moderate Alzheimer Disease Cooperative Study. JAMA 283:1007-1015.

Nathan L, Chaudhuri G (1997) Estrogen and atherosclerosis. Annu Rev Pharmacol Toxicol 37:477-515.

Norfleet AM, Clarke CH, Gametchu B, Watson CS (2000) Antibodies to the estrogen receptor-a modulate rapid prolactin release from rat pituitary tumor cells through plasma membrane estrogen receptors. FASEB J 14:157-165.

Olsen NJ, Kovacs WJ (1996) Gonadal steroid and immunity. Endocr Rev 17:369-384.

Pagenstecher A, Stadler AK, Kincaid CL, Shapiro S, Campbell IL (1998) Differential expression of matrix metalloproteinase and tissue inhibitor of matrix metalloproteinase genes in the mouse central nervous system in normal and inflammatory states. Am J Pathol 152:729-741.

Patrone C, Pollio G, Vegeto E, Enmark E, de Curtis I, Gustafsson JÅ, Maggi A (2000) Estradiol induces differential neuronal phenotypes by activating estrogen receptor alpha or beta. Endocrinology 141:1839-1845.

Polan ML, Loukides J, Nelson P, Carding S, Diamond M, Walsh A, Bottomly K (1989) Progesterone and estradiol modulate interleukin1beta messenger ribonucleic acid levels in cultured human peripheral monocytes. J Clin Endocrinol Metab 89:1200-1206.

Sato H, Seiki M (1993) Regulatory mechanism of $92 \mathrm{kDa}$ type IV collagenase gene expression which is associated with invasiveness of tumor cells. Oncogene 8:395-405.

Schneikert J, Peterziel H, Defossez P-A, Klockert H, de Launoit Y, Cato ACB (1996) Androgen receptor-Ets protein interaction is a novel mechanism for steroid hormone-mediated down-modulation of matrix metalloproteinase expression. J Biol Chem 271:23907-23913.

Schroen DJ, Brinckerhoff CE (1996a) Nuclear hormone receptors inhibit matrix metalloproteinase (MMP) gene expression through diverse mechanisms. Gene Expr 6:197-207.

Schroen DJ, Brinckerhoff CE (1996b) Inhibition of rabbit collagenase (matrix metalloproteinase-1; MMP-1) transcription by retinoid receptors: evidence for binding of RARs/RXRs to the -77AP-1 site through interactions with c-Jun. J Cell Physiol 169:320-332.

Shi J, Panickar KS, Yang SH, Rabbani O, Day Al, Simpkins JW (1998) Estrogen attenuates overexpression of beta-amyloid precursors protein messenger RNA in an animal model of focal ischemia. Brain Res 810:87-89.

Shimizu T, Wolfe LS (1990) Arachidonic acid cascade and signal transduction. J Neurochem 55:1-15.

Tang M-X, Jacobs D, Stern Y, Marder K, Schofield P, Gurland B, Andrews H, Mayeux R (1996) Effect of estrogen during menopause on risk and age at onset of Alzheimer's disease. Lancet 348:429-432.

Toran Allerand CD, Singh M, Setalo Jr G (1999) Novel mechanisms of estrogen actions in the brain: new players in an old story. Front Neuroendocrinol 20:97-121.

Van Dam A-M, Bauer J, Man-a-hing WKH, Marquette C, Tidlers FJH, Berkenbosch F (1995) Appearance of nitric oxide synthase in the rat central nervous system after virus infection and during experimental allergic encephalomyelitis but not after peripheral administration of endotoxin. J Neurosci Res 40:251-260.

Vegeto E, Pollio G, Pellicciari C, Maggi A (1999) Estrogen and progesterone induction of survival of monoblastoid cells undergoing TNF- $\alpha$ induced apoptosis. FASEB J 13:793-803.

Webb P, Nguyen P, Valentine C, Lopez GN, Kwok GR, McInerney E, Katzenellenbogen BS, Enmark E, Gustafsson JA, Nilsson S, Kushner PJ (1999) The estrogen receptor enhances AP-1 activity by two distinct mechanisms with different requirements for receptor transactivation functions. Mol Endocrinol 13:1672-1685.

Xu X-P, Meisel SR, Ong JM, Kaul S, Cercek B, Rajavashisth TB, Sharifi B, Shah PK (1999) Oxidized low-density lipoprotein regulates matrix metalloproteinase-9 and its tissue inhibitor in human monocytederived macrophages. Circulation 99:993-998.

Yong VW, Krekoski CA, Forsyth PA, Bell R, Edwards DR (1998) Matrix metalloproteinases and diseases of the CNS. Trends Neurosci 21:75-80.

Zancan V, Santagati S, Bolego C, Vegeto E, Maggi A, Puglisi L (1999) $17 \beta$-estradiol decreases NOS II synthesis in vascular smooth muscle cells. Endocrinology 140:2204-2209. 